EFI: $\mathrm{ECT}$

II -1
DEPAPTIENT OF COLIERCE

BUREAU OF STANDAPDS

TASEITGTON

Auguist 2, 1923.
Letter

Circular

IC 100

\title{
OIL HEATIIVG
}

1. Nunerous inquiries have been received by the Bureau in rererence to the actisability of substituting oil for coal as a fuel for house heating. The following general infornation has been compilea to meet such incuiries.

2. The advantages usually claimed for oil fuel are cleanliness convenience, better control of the fire, availability of the Iuel at times wher coul can be ootained with difficulty, if at all, and sometimes loiter cost of Iuel.

3. There are also possibie disadvantages connected with the lise $\dot{0}$ oil fuel, anong which waj ce menticned, ocior, noise, higher cost, due to high First cost of some tjpes of instaliations, higher operating cost, and increased fire risk.

4. Mith a suitable installation, it is unouotedy true that oil vill de superior on tile grounds of cleanliness and convenience as JeII as ease of control. The matters of odor and noise vili depanci upon tine fuel used and the type of irstallation and information ucon these features should be obtained before making a purchase. The noise way be due either to the roaring of the Ilame or to a mechanical apoliance, such as a motor driven fan. It should se vorne in minc that noise due to mechanical apoliances tendis to increase as the appliance becones older. A noise that way apear to be unimportant in an installation on exhibition, thay, to a person of nervous temperament, beco:e intolerable if continued, either continuously or intermittently, for ertended periods.

5. The use of oil undoubtedIy involves a greater fire risk than the use of coal. The greater hazard, however, usually leads to the adoption of additional precautions, wich in many localities are wandator. Furthermore, some of the oil burning aplianoes have jeon tested tith rereronce to fire hazard, and ajoroved by the insurance interests. It may be said in general, that if en installation is aporoved by tho insurance interests, the ire risk is reduced though not abolutely provided for.

6. Outside of the tuestions considered in the tro preceding paragraphs, there remain tine questions of availability and cost, Wich are rather intimately related. At the present time, (1923), wost of the oil-burning aopliances sold for house heating burn 
<smiles></smiles> 
kerosene or a similar light oil and are not designed for using the heavy and cheap fuel oils. At the cresent tine, the amount of kerosene rhich can be producec is in excess of the de:rana, but any extensive introduction of oil burning appliances for house heating rould probably result in a derand for this grade of Ivel which vould greatly influence the price. In the future, oil-Durning installa tions wich can utilize the heavier grades of fuel will undoubtedly have a distinot aciantiage, not only on account of the lorer price, but on account of the greater quantity of such fuels ava ilable. For the present, horever, such installations are apparentiy not on the market and consiclering only these types which use a fuel something like keroscne, it way be said that in the long run, it is possibie that vscrs of oil burners may have as much dificiculty in obteining fueJ, as the users of coal, but during the next for years it is quito possible that there will be periods when oil can bo much roro casily obtained than coal.

7. The a-vaila-bility of a particuiar grade of fuel may depend upon the locality. It is probable that in most of the smaller cities of the country, a barrei of low girace ineI oil, delivered. to the custoner would at present cost more than a barrel of kerosene, in spite of the fact that the cost of the fuel oil, at a distributing center, might be only one-third that of kerosene. Before installing any type of oil-burning equiprent, the purchaser shouid, of course, assure himsolf that mears are available for supplying the grade of inel required.

8. Tho relative cost of heating rith oil and rith coal in any particular installation, could not in general be determined without detailed data, but certain genoral considorations are of interest. The combustion of one pound of oil will yield about 18000 Btu (A British therinal unit, or Btu, is the amount of neat required to raise the temperature of one pound of rater by $10 F)$. Assuming an oil Jeighing seven pounds per gallon, its heat of conbustion rovld be about 125000 Btu per gallon. The ainount of heat winich cain be produced by the complete combustion or a, pound of coal ranes irom over $14000 \mathrm{~B}$ tu for the higher grades to belor 10,000 Btu for the Ioter grades. In the folloning it vill be assuined. that coal as sold For domestic heating has a heat of combustion of 12500 Btu per pound. Ore gallon of oil has therefore about the sane heat of coibustion as ton pounds of fairir good coal.

9. In order to heat a house a cortain numor of Btu must be supplied, and the cost of heating, other things being equal, Till be oroportional to the cost per Btu, or per milion Btu. In the folloring table the cost of a milion Btu or rather the cost of 8 galions of oil is compared with the cost of 80 los. of coal, each of wich if completely burined, would according to the preceding paragraph, yield a miliion Btu. 

Cost of Oil per Galion:

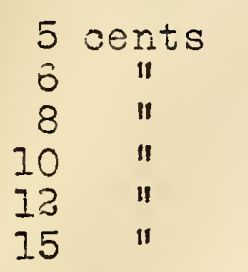

Gost of 8 GaIE. (1) Vilizion Btu)

$\begin{array}{rl}\$ 0 & .40 \\ . & 48 \\ . & 64 \\ . & 80 \\ .96 \\ 1.20\end{array}$

Cost of Coal Cost of 80 Ibs. per 2000 Ibs. (I milition Btu)
$\$ 0.20$

.24 .32

.40

.48

.60

10. From the above table it might be inferred that coal at $\$ 15.00$ per ton of 2,000 lbs. was equivalent to 0 il at about 8 cts. per galion, or that heating with cil at 12 cents per gallon would. cost twice as much as heating vith coal at 12.00 per ton. Such a comparison would probably be unfeir to oil, for a number of neasons. Caal is never burred completely, mhile the losses due to incomplete combustion of oil are probably. very small in a good installation. A suitabie tyce of oil burner vill permit a close control of the fire and for this reason oil heating might be much less rasteful than coal heating.

11. A fairer comparison may perhaps be made by assuming that of the heat of combustion of coal $40 \%$ is usefully applied, while with 0 il, $60 \%$ is usefully applied in domestic heating. This would mean that oil is used l-1/2 times as efficiently as coal. If this is trile, the cost per milion Btu, actually utilized rould be as shom in the following table:

Cost per million Btu. With $0: 1$ heating ( $60 \%$ efficiency) and coal neating ( $40 \%$ efficiency.)

Cost of $0 i 1$ Cost cer Cost of Coal 2er gallon. Million Btu. Per short torl Per long ton Million Btu.

\begin{tabular}{|c|c|c|c|c|}
\hline $\begin{array}{rc}5 & \text { cents } \\
6 & " 1 \\
8 & 11 \\
10 & " 1 \\
12 & " 1 \\
15 & " 1\end{array}$ & $\begin{array}{r}\$ 0.67 \\
.80 \\
1.07 \\
1.34 \\
1.60 \\
2.00\end{array}$ & $\begin{array}{r}\$ 5.00 \\
6.00 \\
8.00 \\
10.00 \\
12.00 \\
15.00\end{array}$ & $\begin{array}{r}\$ 5.60 \\
6.70 \\
8.95 \\
11.20 \\
13.10 \\
16.80\end{array}$ & $\begin{array}{r}\$ .50 \\
.60 \\
.80 \\
1.00 \\
1.20 \\
1.50\end{array}$ \\
\hline
\end{tabular}

12. In making comparisons, the cost per short ton or long ton of coal may be used according to the vay the coal is oought, and comparison based on prices which prevail or seem likely to prevail, may be made. The figures in the table seem to correspond fairly well with the experience in the very fer cases in which information vas obvained as to the relative cost of heating Jith oil and ritin coal. 

13. There are a Iarce nubs oI oil burning appliances on

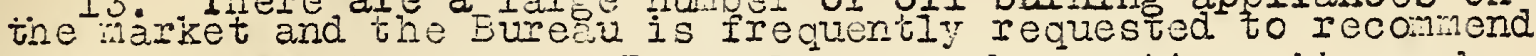
the nost efficient one. In reply to such questions it may oe siated that an appliance inich is ineficient is very likely to produce a great deal of suoke, so that the efficiency of the ourner as such usually proclains itself. In reference to durability, reliability, ett., the Bureau has made no tests or exaninations or tine various appliances, and if it had it rould rot be at liberty to make specific recommendations on competitive producis. It nay be said, honever, that the vaooriaing type of burner wich can easily be asseinbied frou a fer castings and pieces of pipe is in gencral unsatisfactory. In such burners, the oil is vaporizea in a cIosea pipe on casting, and the vapor issuing from vory sinal holes is ignited ard bhe burning, heats the oil in the closed pipe, thus orctidirs a continous supply of vapor. Such burners operate well or gasolire, but with heavier oils, have a tendency to clog, and reauire constant attention. To start such a bumer the vaporizer must first be heated, which is sometimes done vith rood alcohol. or gasoline, scmetines tith kerosene, in case the smoke produced is no\% too objectionabie. The burners on the market range from this simple type to much more elaborate systems wich are sold at a price comparable with the cost of an ordinary heating plant.

14. It is $7 e$ II to bear in mind wen examining oil burning ap pliances, to observe ease of starting, ease o: cortrol, adaptability to autonatic control, and to disregard clains as to hotness of flame, eto. If combustion is reasonably comietie the amount of seat rinich can be ojtained rith a vuner depends upon the anount of oil burned, and not upon the apoerance of the flawe. In reference to any appliances, the purchaser sinould assure himself that the nanufacturex is reliabie and likely to conitinue in business, and that prompt and reliajle service in oase repairs are necessary, will be arailable.

I5. Most oil-burning agoliances as no\% sold are intended for installation in a coal burning heater. It might be expected that a complete installation designed for cil ourning, would prove nore efficient and satisfactory in general than a converied coal burnor. Or the other hand, the possibility of retumning to coal burring in case oil reating for any reason proves to be or later becones unsatisfactory, may prove to be of great value.

16. This letter is sent out only in reply to individual inquiries and publication of its contents either in whole or in part, is not avthorized. 


